\title{
Pictorial Narration of Paulo Coelho
}

\section{Jothi}

\begin{abstract}
Fiction emerges from a writer's experience and imagination. It embraces the present, the past and the future and proffers values to hold on to as well as dreams to reach for. At its best it makes us look at life from a new perspective. A work of fiction is an imaginative narrative writing in prose. Believable characters, convincing dialogue and an interesting plot are among the essential ingredients of fiction. Because fiction writers share their thoughts with us through words, the writer's style- the words that the writer chooses and how he puts them together - are critical to our understanding of the craft of a given work and of its effect on us. Like any other work of art, fiction offers us a vicarious experience. The ways in which we derive enjoyment from reading fiction are countless. Paulo Coelho is one of the most influential, widely read, and loved authors in the world. He is the recipient of numerous prestigious international awards, among them are the Crystal Award by the World Economic Forum and France's Legion d' Honneur. He was inducted into the Brazilian Academy of letters in 2002. But instead than offering readers enticing stories of savagery, excitements or sex, Coelho composes of normal individuals who place themselves in unprecedented circumstances to develop their internal identities, utilizing simple, unadorned exposition.
\end{abstract}

Keywords : Characters, Choice of diction, Dialogue, Experience, Fiction, Imagination, Plot.

\section{INTRODUCTION}

A narrative is a story or part of a story. It might be spoken, composed or envisioned and it will have at least one points of view speaking to a few or the majority of the members or onlookers. In stories told orally, there is an individual recounting to the story, a storyteller whom the group of spectators can see and/or hear who adds layers of importance to the content non-verbally. The storyteller additionally has the chance to screen the group of spectators' reaction to the story and adjust the way of the advising to explain substance or improve audience's advantage. This is recognizable from the composed structure in which the writer must measure the peruser's conceivable responses when they are unraveling the content and settle on a last selection of words in the expectation of accomplishing the ideal reaction. Whatever the structure,may concern genuine individuals and occasions; this is named Personal Experience Narrative. At times the storyteller might be one of the characters in the story. Roland Barthas portrays such characters as "paper creatures" and fiction includes their accounts of individual experience as made by the creator. When their thoughts are included, this is termed Internal Focalization (Wikipedia the free encyclopedia <http:en. Wikipedia. Org/Wiki/Narrative>). When each character's mind focuses on a particular event, the text reflects his reactions. Narrative can then be used to obtain a richer understanding of the complex issue.

Coelho was always a nonconformist, a seeker after the new, leading him to try everything good and everything bad that appeared along the way. He took part in all the progressive movements and was part of the peace and love generation. It was then that Coelho began to experience his

Revised Manuscript Received on December 20, 2019.

C.Jothi*, Department of English, Kalasalingam Academy of Research and Education, Srivilliputtur, India, Email:jothic.phd@gmail.com crisis of faith and went off in search of new spiritual experiences, resorting to drugs, hallucinogens, sects and magic, travelling all over Latin America in the footsteps of Carlos Castaneda. He began his life as a journalist, then as a lyricist with the help of the music producer Raul Seixas (the one whom he has mentioned in The Valkyries). There were also the years when he had his most intense experience with black magic, as inspired by Aleister Crowley, one of the hardest and most difficult experiences of his life, which he profoundly speaks about in depth in Paulo Coelho Confessions of a Pilgrim.

\section{EXPERIENCE OF THE PILGRIMS}

The experience of the pilgrimage to Santiago drove him to publish what would be his first literary text: Diary of a Magus (later re- titled The Pilgrimage). After this came his other books from The Alchemist to the recent Veronica Decides to Die, establishing him as one of the ten best- selling authors in the world, an author who stirs up controversy and extremes of passion, but who continues smiling and sure on his path to awaken the lost taste of mystery and magic in men and women at the beginning of this new millennium, overcoming tedium and helplessness in the bosom of a mechanized and bored society. Coelho often says he has enough money for three reincarnations. He earns so much that he has committed four hundred thousand lakh dollars a year of his author's royalties to a foundation that carries his name and which his wife, Christina administers. The money is used for the case of abandoned children in the worst slums of Rio, for the poor and needy elders, to promote the translation into other languages of Brazilian classics and for investigation of the fossil origin of his much - loved Brazil, which he considers the most magical country in the world because, as he says, in Brazil, there is no difference between the sacred and the profane and no one is ashamed to believe in the spirit (Paulo Coelho Confessions of a Pilgrim xii).

Many of Coelho's readers will wonder what his private life is like, how one of the world's most widely-read writers behave behind closed doors, what are his fears, his small satisfactions, and his worries? Those lucky enough to know the man well, might point out that such a celebrity does not really exist, because Paulo Coelho despite his fame, the millions of dollars his work earns him, the international demand for his presence - is a totally approachable, available, generous, simple person, almost childlike at times. A person who does not hide the black spots of past and the positive reception that greets his books, especially from young people. He tends to forget the negative reactions as quickly as he hears them. He believes jealousy to be the best sin just as the most moronic. Coelho is a character with extraordinary interests, incredible imperfections, once in a while with incredible virtuoso, with his little weight of vanity, fit for being extreme when he needs to be. In any case, at the sametime, he has an extraordinary limit with respect to commitment and a true want to help other people locate their own fate. That is what

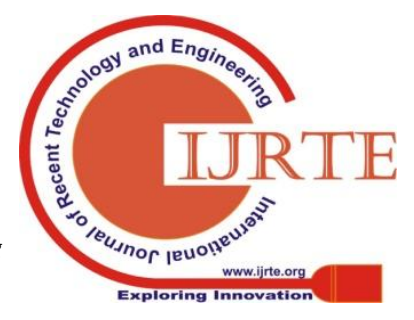


has saved him from a difficult, sometimes tragic past and it is that which has taken him more than once to the edge of madness and death. When Coelho talks about the horrible death, he says, "I was never terrified of death because I saw it up close so many times" (Paulo Coelho Confessions 54).

Paulo Coelho once said that following one's fantasy resembles learning an unknown dialect; one will commit errors however one will arrive at last. In 1988, he distributed The Alchemist. An epic that investigates this topic and it propelled him as a universal top of the line creator. In particular, Paulo Coelho is perceived for his incredible narrating system and the significant otherworldly experiences he mixes consistently into his stories. His personal life lays foundation for the creation of most of his novels. Part of his own hardships of life has been depicted through the protagonists of his works. His indulgence in the impact on black magic has been described in The Valkyries; his resuscitation from the evil society to spiritualism that has sprouted due to his pilgrimage to Santiago-de-Compostela has been recounted in The Pilgrimage and his strife to become an accomplished professional writer, has been traced in The Zahir.

\section{UNDERSTAND THE DESIGN}

For Paulo Coelho, the main wrongdoing against life is to have faith in "unthinkable". As per him, every individual has a task to carry out, a real existence design that is remarkably intended for a person. What's more, satisfaction lies in following and understanding that design, being your identity, rather than strolling on the trodden way (An Interview with BrazilianSpiritual Asp Fiction Writer, Paulo Coelho <http://www. life positive. com/spirit/traditional path's/sorcery/coelho $>$ ). One of the salient features of Paulo's narrative styles is usage ofsymbols: the magical sword which the protagonist goes in search of in The Pilgrimage, the hidden treasure of an Andalusian boy Santiago in The Alchemist, the Mojave desert in TheValkyries, sex in Eleven Minutes, the bloodstained cloth in The Zahir, dance in The Witch of Portobello and the thirst for magic in Brida -these symbols enhance the searcher or theprotagonist to arrive at their destiny.

In all the above mentioned novels, the author gives more significance to travel. In course of the journey undertaken by the protagonists, they refine their soul and seek spiritual enlightenment. The protagonist's passion for his all powerful magical sword in The Pilgrimage stimulates him to travel all the way from Spain to Santiago. In the novel, the all powerful magical sword symbolizes the protagonist's unquenchable thirst for magical power and his desire to become all powerful. On the way, he beholds tremendous impediments that whet his soul and he learns to tackle it even unguided. When he reaches the spot where his magical sword is hidden, after crossing a sea of obstacles, his anxiety, desires and monetary pleasures vanish. He extracts the essence of life through his journey. Similarly in the case of the Andalusian shepherd boy Santiago in The Alchemist, it is his hidden treasure which is symbolized to him through his dream. The novel does not talk about leaving everything to pursue one's dreams. It just says that one should have dreams and move towards them. A vast number of books have been written about the interpretation of dreams. The protagonist has a dream of a distant treasure in the Egyptian Pyramids and the courage to follow it. He ventures to undertake his journey of exploration and self - discovery symbolically searching for the hidden treasure located near the pyramids in Egypt. The phenomenon of converting an ordinary metal into gold is alchemy.

\section{THE HIDDEN TREASURE}

The hidden treasure in The Alchemist acts like a catalyst in converting a shepherd boy into a visionary. He lacks his curiosity in accumulating money due to the struggles he encounters on the way towards the pyramids in Egypt where his cherished treasure is said to have been hidden. The moment he becomes rich, he loses everything. Throughout his quest towards the treasure, he endures physiological and psychological torments. He judges that "when you desire something, all the universe conspires in helping you to achieve it" (23). The protagonist arrives at the pyramids only to be beaten by the desert robbers. Finally when he discovers his buried treasure from under the sycamore tree, the precious stones and jewels inside the box do not tempt him. He cherishes them not as a pandora's box but as a love of his beloved that has aflamed him to achieve his destiny. He affirms that "to realize one's destiny is the real obligation of life" (23). Like the buried treasure in The Alchemist and the magical sword in ThePilgrimage, it is the Mojave desert in The Valkyries.

The protagonist and his wife's channelling start in the Mojave desert. His wife, Chris, feels the state of euphoria at the extremity of the heat of the desert. They are rescued by Gene who assures them of meeting Valkyries on the desert. In a nutshell, the desert enables the author to discover new aspects of psyche, to develop new angles on his existing skills. The couple accomplishes all rituals on the desert. Till the end, the protagonist waits contemplating on the desert for his angel to appear. His halt on the desert imparts and replenishes his soul with patience and contentment. The desert here acts as an agent to establish the hidden treasures of human soul to rejuvenate itself. The serenity of the sand pacifies the tribulations of the travellers thereby enabling them to communicate with the mystical powers such as nature, universe, and the Superior energy that accompany them during their journey. The desert is a central setting in most of Coelho's novels. The coinciding double implications of the desert being a cruel, dormant spot, and being where supernatural quality and change have occurred, make the desert an enchanted pragmatist space. David Jasper clarifies in his book The Sacred Desert, that as the desert is physically the harshest spot on earth, deserts additionally challenge our feeling of the real world, its extents and the limits we set on our lives and experience (Magical RealistTransformation in The Witch of Portobello <http://www. flipkart. com/the Wtich-of - Portobello Paulo - Coelho - book - 0007278594). The desert becomes a space where body and soul exist amalgamated in oneness. According to Jasper, "Language and the desert sands, wherein dried but living roots are buried waiting for the rain, share a common life" (Magical RealistTransformation 
<http://www.flipkart. com/the witch - of - portobello - paulo coelho - book - 0007278594>). The desert's mystic connotation in relation to literature seems to transform thedesert into a space where language exists within the silence of the place, and that the concept of time transforms into timelessness. Sex was always surrounded by taboos. But sexuality is first and foremost the way that God chooses for love in the physical plane, rather treating it as a manifestation of evil. It is the major exploration confronted by Maria in Eleven Minutes. Paulo Coelho voices this sensitive issue in this novel. He tries to meditate the gap between the protagonist, Maria's individual consciousness and the outer world that shapes the inner life of Maria. The most mysterious part of this book is the protagonist's quest through sex which illuminates her inner glow. Here sexuality does not assume the guise of lust. On the other side this sexual introspection makes sex more sacred.

In the beginning, Maria becomes dejected by disillusioned love that has resulted out of her adolescence but later she cherishes love. She feeds other's thirst for lust by dedicating her physique but her soul remains unquenched until a genuine love (Ralf Hart) crosses her path. Her spirit overflows with the love of Ralf Hart, hence she declares that love never askshow one confounds sex and love - and how one never again is by all accounts ready to discover the affection in sex. The opening sentence "Quite a long time ago, there was a whore named Maria" (01) lamentably sets a cool, generic tone that takes Coelho a few sections to survive. Obviously Maria isn't a normal whore - if there can be such an individual - and her novel point of view frames the spirit of Eleven Minutes. It is a heavenly mission through sex. What is sex? This is the This is the thing that Coelho is by all accounts asking and at last replying in this impossible novel. For, to Coelho, climax and the delight of sex clearly are the doors to a definitive emblematic association with the perfect. As a man, heinvestigates a lady's sexuality and the association with otherworldliness.

In The Zahir, the author's life is full of anxiety on account of the disappearance of his frustrated wife who has a mission of spreading the energy of love among the people by distributing a piece of blood stained cloth. The author's wife Esther is a war correspondent. She gets the blood stained cloth from a soldier who was the first to realize the flow of love and he wishes it to continue. When the author begins to probe the reason for his wife's disappearance, in each step he finds ordinary people preserving the blood stained cloth presented by Esther. Almost all walks of people possess a

piece of blood stained cloth with a symbol Lu in some form or other. The author ironically does not have this piece of blood stained cloth and realizes their mission of spreading the energy of love. He too longs to share that warmth of love and believes that the soul of the world has to allow him to find his Esther. He is utterly mystified and yet awaits the mystery to unveil itself. On their meeting in Kazakhastan, Esther gives him a piece of blood stained cloth of a soldier. He introspects himself only when he was able to understand the flow of love. Dance acts as a medium of quest in both The Witch of Portobello and Brida where the protagonists - Athena and Brida seek spiritual fulfilment. Their unrhythmic dance to the sounds either aroused by the surrounding or to the music played, enables them to step into a mysterious world where their souls feel elevated. Dance is one of the significant subjects in both the books. It turns into an image for change. As a rule, move is a fine art that alludes to developments of the body, generally cadenced and to music, utilized as a type of articulation, social connection or introduced in a profound or execution setting. In The Witch and Brida, The protagonists do not dance in accordance to a particular rhythm. They dance to the unrhythmic music present in nature as a means of communication with divine. They dance in a nonsync motion, closing their eyes, lifting their hands until they are transformed into something unknown. This unrhythmic dance lights their inner soul and enables them to communicate with the Superior Being. Though the motive behind their transcendentalism is different, the path that they choose to reach that extent remains the same. Athena the protagonist of The Witch is more cautious that she should not be titled as 'witch' in course of her spiritual learning. Her only motive is to spread the energy of love among people like Esther in The Zahir. On the other hand Brida longs to become a witch and so she learns magic. But the destiny of these protagonists also vary that the former is misinterpreted as a witch and is believed to misguide people yet her disciples acknowledge her mysterious power of healing diseases and prophesying. As for Brida, through her witchcraft, she learns about "soulmate" and also discovers her true soulmate "the Magus" despite having fallen in love with Lorens, her beloved.

The protagonist in The Pilgrimage travels on the ancient road of pilgrims-Santiago de Compostela to discover his magic sword with which he has performed millions of brave deeds, which lies hidden in one of the Cathedrals. Coelho introduces many strange things to us. He explicates one's personal demon in the shape of a vicious dog. The protagonist vanquishes his dread with the obscure forces that show in him as though by enchantment. Attempting to gather his considerations and emotions, while nearly being deceived by an alleged evil spirit, Paulo Coelho runs over a bunch of occasions that advise him that straightforwardness holds more noteworthy control over all. The way to Santiago is also called a street to self-acknowledgment. The voyage to Santiago is to become familiar with life and straightforward things that it brings to the table. An account of this experience on the Road to Santiago has been shared by Paulo Coelho in The Pilgrimage. This ancient road, road to Santiago plays a prominent role in the life of Maria, the protagonist of Eleven Minutes. Maria, a prostitute, happens to walk on the road to Santiago that passes through Geneva a common road for all. This incident brings a change in her life. When her feet touch the road, she becomes wiser. She feels the divine power on it. The moment she steps on the road, Maria's body and soul begin to become reintegrated because of love. Some transformation takes place in Maria. She starts her spiritual quest with Ralf Hart-the man who recognizes her soul.

Eleven Minutes stands apart from all the other novels. For, sex which is treated as a taboo, has been the hub of this novel. While other protagonists quest through various medium, Maria quests through sex to reach spiritual awakening. None prefers to become a prostitute but Maria prefers to be so. In her adolescent age, she too has the whims and fancies like other young girls of her 
age. Her dream flies farther than her approach [...] her prince charming would arrive, sweep her off her feet and take her away with him so that they could conquer the world together (Eleven 01). The fanciful thoughts of an adolescent girl how she dreams to find a boy like a prince, of getting married to him, bearing children leading a sophisticated life in a lovely house with a sea view-are the general imaginations of all young girls. The disappointments that she meets with gentlemen force her to create a wrong notion about love because of which she becomes a prostitute.

\section{EXCEPTIONAL NARRATION}

Through The Alchemist, Coelho presents a straightforward tale, in view of basic realities and spots it in an exceptionally interesting circumstance. Not only Santiago learns about the process of alchemy but also the readers. It is believed that if a metal was heated for many years, it would free itself of all its individual properties and what was left would be the "soul of the world" (158). The ensuing student-teacher relationship between the Alchemist and the shepherd boy clarifies much of the boy's misguided agenda, while also emboldening him to stay true of his dreams. "My heart is afraid that it will have to suffer" (137) the boy confides to the Alchemist one night. The Alchemist replies "Tell your heart that the fear of suffering is worse than the suffering itself" (137). Similarly in The Valkyries, Coelho's quest starts with the secret of his spiritual master's (J) words.

As an author, Coelho creates a powerful setting which is tense and obscure. The real Coelho is human and full of his own questions. His knowledge of the desert is questioned when he and his wife set out on a long walk through the mysterious sand dunes. They set themselves free by letting their nude bodies be devoured by the scorching sun. Coelho coins a new term "second mind" (27) which his wife Christina first learns to quieten and figures out how to talk with her angel, before Coelho does. Feeling exhausted due to their tedious walk in the desert, they fall down on the sand unable to bear the extremity of the hot sun. Yet in such a situation, Chris feels a state of euphoria. She calls it as "her soul has grown" (45). On their long treacherous journey, they meet Valhalla and the Valkyries who take them to perform various rituals to enable them meet their angel. The exasperated Coelho finally meets his angel, after much disappointment, in the desert. An astonishing mix of the intriguing regions, sensational experience and otherworldly narrating, for which Coelho's anecdotal works are prestigious, this genuine life record is without a moment's delay a cutting edge experience and a mystical odyssey.

Besides, Coelho's construction of sentences makes the readers get absorbed towards their reading. It might be one of his techniques to present catchy short sentences that deserve to be a maxim. For example,

- We always know which is the best road to follow, but we follow only the road that we have become accustomed to (The Pilgrimage 53).

- Death is our constant companion and it is death that gives each person's life its true meaning (123).

- To realize one's destiny is a person's only real obligation (The Alchemist 23).

When you desire something, all the universe conspires in helping you to achieve it (23).

Love is the force that transforms and improves the soul of the world (158).

- Everything that happens once can never happen again. But everything that happens twice will surely happen a third time (164).

When God wants to drive a person insane, he grants that person's every wish (TheValkyries 236).

Love was work everything and couldn't be exchanged for anything (225).

Follow your dreams and take your risks (142).

No one loses anyone because no one owns anyone (Eleven Minutes 92).

Really important meetings are planned by the souls long before the bodies see each other (140).

- If you want to achieve your objectives, you have to be prepared for a daily dose of pain or discomfort (173).

When a teacher helps someone to discover something, the teacher always learns something new too (177).

- $\quad$ Suffering occurs when we want other people to love us in the way we imagine we want to be loved and not in the way that love should manifest itself (The Zahir 337).

- Loneliness gets stronger when we try to face it down, but gets weaker when we simply ignore it (The Witch of Portobello 66).

- It is well to give when asked but it is better to give unasked (190).

- Anyone who believes they have failed will always fail. Anyone who has decided that they cannot behave any differently will be destroyed by routine (239).

- What you give you will receive, although it might sometimes come from the place you least expect (229).

- Changes only happen when we go totally against everything we're used to doing. (224)

- Take great care with everything you say, the word has more power than many rituals (Brida 84).

- Love between people is much more difficult to understand than love for a Supreme being (215).

- Accept what life offers you and try to drink from every cup (254).

\section{CONCLUSION}

Simple incidents narrated with vivid descriptions and uncomplicated sentence constructions make these novels perfectly delightful. Like an Alchemist, Coelho adds just the right mix of mysticism and realism, love and fear to make his novels a wonderful experience. He is a master storyteller and the readers find it easy to be magically transported to an ancient parallel universe.

\section{REFERENCES}

1. Coelho, Paulo. The Pilgrimage, New Delhi; Harper Collins Publishers India Ltd, 1998. Print.

2. Coelho, Paulo. The Alchemist, New Delhi; Harper Collins Publishers India Ltd, 1998. Print.

3. Coelho, Paulo. The Valkyries, New Delhi; Harper Collins Publishers India Ltd, 1998.

4. Coelho, Paulo. Eleven Minutes, New Delhi; Harper Collins Publishers India Ltd, 2003. 
5. Coelho, Paulo. The Zahir, New Delhi; Harper Collins Publishers India Ltd, 2005.

6. Coelho, Paulo. The Witch of Portobello, New Delhi; Harper Collins Publishers India Ltd, 2007.

7. Coelho, Paulo. Brida, New Delhi; Harper Collins Publishers India Ltd, 2008. Print.

8. Abrams, M.H. A Glossary of Literary Terms, $7^{\text {th }}$ (ed) New Delhi; MacMillan India Ltd 2001.

9. Arias, Juan. Paulo Coelho Confessions of a Pilgrim, South America. Harper CollinsPublishers India Ltd, 2007. Print.

10. Bhatia. H.S. English Literature, New Delhi; Ramesh Publishing House, 2005.

11. Bowers, Maggie Ann - Magic(al) Realism, Routledge Taylor \& Francis Groups London and New York, 2007. $1^{\text {st }}$ Indian Reprint.

12. Chakrabarti, Mohit. Rabindranath Tagore - A Quest, Gyan Publishing House, NewDelhi, 1995.

13. Danow, David.K. The Spirit of Carnival : Magical realism and the Grotesque,

Kentucky : University Press, 2004

14. Iyengar, Srinivasa. K.R. The Adventure of Criticism-Existentialism and After, New Delhi; Sterling Publishers Pvt Ltd, 1985. Print.

15. Jee Maharaj, Swami Chidatman. Indian Mysticism, Anmol Publications Pvt.Ltd. India, 2009.

16. Littcrit: The Theme of Suffering in the Selected Fiction of Anita Desai.ed

A.Namasivayam, Vol.43. New Delhi: Jamia Millia Islamia University, 2008.

17. Nayar, Pramod, K. Post Colonial Literature-An Introduction, India: Pearson Longman Publication, 2008.

18. New Combe, T.M. Social Psychology, New York: Oxford University Press, 1990.

19. Saxena. O.P. Glimpses of Indo-English Fiction, Vol - I New Delhi: Jaisons Publication.

20. Sharma. K.L. Indian Society, New Delhi : NCERT, 2000.

21. Thomas, Kadankavil. Ethical World, Bangalore: Dharmaram Publication, 1995.

22. Trikha, Manorama. B. "Mythical Experience in Tagore's Poetry", Perspectives onRabindranath Tagore. ed. T.R.Sharma Ghaziabad: Vimal Prakashan 1986. NewDelhi.

23. Vineeth. V.F. Foundations of World Vision, Bangalore : Dharmaram Publications, 1985

24. "Indian Mysticism" The Hindu 15 Oct. 2010

25. "Mysticism" The Hindu 12 Aug. 2009.

26. "Religion - Spiritual Quest" The Hindu 10 Nov. 2008.

\section{AUTHORS PROFILE}

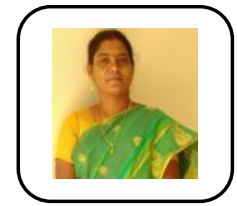

Dr. C. Jothi, M.A., M.Phi.,l Ph.D. was the former head of the Dept. of English,Kalasalingam Academy of Research and Education, Deemed to be University, Krishnankoil, Tamilnadu. Presently she is serving as Assistant Professor-II for the same University .Graduating from M.V.M Govt. Arts College,Dindigul, she did her Ph.D. in Gandhigram University under the guidance of Dr. S. Laxmi who had been instrumental and inspirational for her research accomplishments on the Brazilian writer, Paulo Coelho. She has presented and published many articles in literature, has attended many Workshops and Training Programmes to her credit During her tenure as a Head, she had organized two 3 Day Faculty Development Programmes, 18 Guest Lectures, Employability Training Programmes for students and a Workshop on Relax and Unroll for faculty. As an ardent reader and meticulous mentor, Dr. C. Jothi has to her credit been fervently teaching literature and criticism and guiding many aspirant scholars in their pursuit of knowledge. She has published a book entitled Mystical Quest in the Novels of Paulo Coelho. Besides, she is an active member ofELT@I. 